\title{
Comparison of Municipal Development Plans of Czech Cities
}

\author{
Adam KOVÁCS, Tibor ZSIGMOND and Renáta MACHOVÁ* \\ J. Selye University, Komárno, Slovakia; 119725@student.ujs.sk; zsigmondt@ujs.sk; machovar@ujs.sk \\ * Corresponding author: machovar@ujs.sk
}

\begin{abstract}
The aim of the article is to compare the municipal development plans of different cities. The research covered cities in the Czech Republic with more than 100,000 inhabitants - excluding the capital, Prague. Five cities met the set criteria: Liberec, Olomouc, Pilsen, Ostrava and Brno. A brief outline of these cities is followed by the presentation of development plans created and approved by the municipalities of each city. In connection with the field of research, we formulate several research questions in order to be able to establish the most relevant results during the analyzes. Based on these, the connections and differences in the perception and purpose of each city can be examined. After outlining the research on the defined objectives and criteria, the results obtained are summarized. In the remainder of the article, we draw the appropriate conclusions based on the results identified. Finally, our article concludes with an outline of possible future directions and plans.
\end{abstract}

Keywords: municipality; development plan; comparison

JEL Classification: 020; 021; P21; P25

\section{Introduction}

According to Rechnitzer (2019) the urban development issues have received increasing attention in recent times, while the direction and institutional framework of regional policy is constantly changing. The aim of the study is to compare the directions of modern municipal development plans of Czech cities. The study deals with cities which have more than 100,000 inhabitants. Rechnitzer (2019) states that in cities with 100 thousand and more inhabitants the urban system is definitely viable.

A municipal development plan is the basic development document of a city, which determines how the city should develop in the coming years. It is based on an assessment of the needs and potential of the city. The priority of a municipality plan is to solve the main problems of a city. Its aim is to create appropriate conditions for the inhabitants. Its main goal is to make the given city more attractive for all citizens, including the functioning of business and non-profit entities. It should make the municipality attractive for potential residents. The municipality plan is a local strategy with a societal impact. Every plan must have a professionally developed strategy which should make impact on all citizens, actors of the city's development and on the immediate surroundings of the city. The plans are based on the need for economic development. Municipality plans create conditions for new activities to ensure employment. Develop and implement strategic asset portfolios to ensure its development and optimizes the management of its assets. It has to develop a system for 
preventing the consequences of crisis events - like the difficulties caused by the Covid-19 pandemic. (Ankers et al., 2020; Hastings, 2021)

In addition to the criteria and framework defined by us, we examine five Czech cities from the perspective of development plans, and through the implemented and planned developments of each municipality and specificities of the plans we seek answers to our research questions.

\section{Methodology}

A secondary research was conducted. In addition to the defined criteria, the subject of the research was the examination of the municipal development plans of the selected cities. In order to give the most relevant image, several research questions were identified.

- What are the goals of the development plans created by the municipalities of the researched cities?

- What are the top priorities of the development plan of the researched municipalities?

- What correlations or differences characterize the researched cities in relation to the development plans?

- To what extent does the location of each city have an influential role in the development plans?

In the present case, aligned with the objectives and criteria set out, the research is descriptive. Appropriate sources and relevant data are explored in the form of secondary data. In the following the paper presents the examined cities from a demographic point of view.

Liberec is situated in the northern part of the Czech Republic, $90 \mathrm{~km}$ from Prague. The city is located in the Liberec Valley on the Žitavsky Plateau - between the Jizera Mountains and the Ještěd-Kozák Ridge. The town is crossed by the river Lužická Nisa, which has two tributaries in the town: the Černá Nisa and the Harcovský brook. It is currently an important center of the region, as the city is the center of the Liberec district and the Liberec borough as well. According to the latest data, it has a population of 103,997, making it the 5th largest city in the Czech Republic - ahead of Olomouc. The city covers an area of $106.1 \mathrm{~km}^{2}$, but it is only the 11th largest in the country. Liberec is one of the most interesting and significant cities in the Czech Republic, thanks to its rich architectural history. The leaders wanted to create a city that resembled Vienna, Munich or Dresden at the time. This was also evident in public and residential buildings. Architecture was greatly influenced by the conservatism of local architects, who mostly followed classicism. Besides them, architects from abroad, mainly from neighboring Germany and Central Europe, had quite a high influence. The image of the city today actually evolved between 1880-1930. It was then that the city's sophisticated infrastructure was developed, and the suburban concept was created.

This sought to emphasize the harmony of nature and the city. However, the second half of the 20th century greatly changed the look of the city. During socialism, the construction of panel houses and residential areas began, so the "concrete sea" flooded the city. This 
phenomenon was typical of almost all cities in the Czech Republic. (Čejka, 2009; Zeman, 2009; ČSÚ, 2018, 2019; Město Liberec, 2021)

The city of Olomouc is an important center of the Czech Republic. According to the latest data, it has 100,494 inhabitants, making it the 6th largest city in the Czech Republic. The city covers an area of $103.33 \mathrm{~km}^{2}$. The city is located in the central part of Moravia, along the Moravian River (hence its name Moravia). It is one of the most important cities in Moravia. Based on the sociographic division of Hampl (2005), Olomouc and its surroundings can be considered as one of the regional centers of the Czech Republic. In addition to Olomouc, there are other important towns in the area, such as Hlubočky, Lutín, Šternberk, Velká Bystřice, Prostějov, Přerev and Lipník nad Bečvou. (Jiř́ičková, 2011; ČSÚ, 2018, 2019)

Pilsen is in the western part of Bohemia and is officially the biggest city in the Pilsen region. It is located at the confluence of the rivers Radbuza, Úhlavy, Úslava and Mže, from where the river Berounka starts. Today, Pilsen covers an area of 13,767 hectares, divided into ten districts. Pilsen, the fourth largest city in the Czech Republic, has a total population of 171,000 . In western Bohemia, Pilsen is dominant as a strong industrial, commercial, cultural and administrative center. The high cultural and economic level is reflected in the individual building developments. Among the most valuable monuments is the gothic cathedral of St. Bartholomew, the Renaissance town hall, the Baroque renovation of the buildings of the Archdeacon and the Franciscan monastery, and the Jewish synagogue. During the 19th century industrialization, the famous industrial giants - the Škoda Engineering Complex and Plzeňský Prazdroj - were established. The construction of a modern industrial zone - Borská pole - is an extraordinary project throughout the Czech Republic. As a result of the efforts to improve the quality of education the University of West Bohemia in Pilsen was founded in 1991. The most valuable traditions of the cultural environment in Pilsen are the work of the J. K. Tyl Theater. Pilsen is a venue for cultural events and festivals of international significance. The year 2015 was a big turning point when Pilsen became the European Capital of Culture. The metropolis of West Bohemia is visited by 3-4 million tourists a year. In recent years, Pilsen has become a sports city, built an Olympic park in 2016 and continued the "Sportmanie Plzeň" project in the following years. (Sykora, 2002; ČSÚ, 2018, 2019)

The most important industrial region is the Ostrava region, focusing mainly on heavy industry. The city is located in the northeastern part of the country and is the largest city in the Moravian-Silesian region. It ranks third in the Czech Republic due to its size and population. The total area of the city is $214 \mathrm{~km}^{2}$ and is divided into 23 urban districts. According to the Czech Statistical Office (CZSO), on 1 January 2018, the population was 291,000. The city is located $10 \mathrm{~km}$ south of the Polish border and $50 \mathrm{~km}$ west of the Slovak border. It is located in a geomorphological complex of the Ostrava Basin which comprises the Ostravice, Odra, Opava and Lučina rivers. Ostrava is a legitimate and cultural center at the intersection of two historical areas of the Czech Republic, namely Moravia and Silesia. The municipality has an extended jurisdiction consisting of a regional court and a regional office. Ostrava is also a major university city with two state universities: The University of Ostrava, located in the city center, and the Technical University of Ostrava, located in the Poruba district of Ostrava. Due to the Leoš Janáček International Airport on the D47 motorway, 
Ostrava is one of the largest traffic hubs in the Czech Republic (ČSÚ, 2018, 2019; Faktografické listy Ostrava, 2019)

Brno is the second most important city in the Czech Republic in terms of both population and territory, the largest city in Moravia, the capital of the historic Margraviate of Moravia. Brno is the center of the South Moravian Region, within which it forms an independent district, the Brno City District. The city is located at the confluence of the Svitava and Svratka rivers, with a population of roughly 380,000 (2019 data). The population of its agglomeration is approximately 800,000 . The permanent population of the area at the 2014 census was 730,000. The city is situated in the South Moravian Region, on the border of the Czech Drahany Hills and the Moravian Lowlands, in the valley of the rivers Svitava and Svratka, next to the D1 and D2 motorways connecting Bratislava with Prague. To the north of the city lies the Moravian Karst, rich in ravines and caves. Brno is also a major center for road transport. The D1 motorway leads to Ostrava, the D2 motorway to Prague and Bratislava. The D52 motorway leads to Vienna, and the planned D43 road will connect Brno with the northern parts of Moravia. The city is also building a ring road around the city. Brno is served by two airports, one of which is the Brno International Airport, whose traffic has grown significantly in recent years. From here there are direct flights to London, Rome, Moscow and St. Petersburg, among others. This airport also serves as a hub for police helicopters. The other is a small grassy airport near Brno Medlánky, it is mainly used by hobby aviators and hot air balloons. Cycling is also very popular, there are 38 kilometers of cycle paths leading through the city. A long - approx. 130 kilometers - cycle path leads to Vienna. There are also many hiking trails crossing Brno. (ČSÚ, 2018, 2019)

\section{Results}

\subsection{Liberec}

The municipality of Liberec has created a complex development strategic plan for the period 2014-2020, which defined the future development directions of the city. It bases on the previous strategic plans of 2002 and 2007 and aims to fill the gaps in these plans. The document assesses the needs and opportunities of the city. The main goal is to make Liberec more attractive to all citizens, regarding the operation of business and non-profit organizations. The implemented strategy affects to some extent all citizens, participants of urban development, those who come to the city for various reasons, and the immediate surroundings of the city. (Jašková, 2019)

In addition to obsolescence, the 2007 strategy also showed some quality shortcomings. In the 2007 version, the measurability indicators were incorrectly set and not properly aligned with the budgetary outlook, actually with the budget. In addition, the municipality had an inadequate organizational structure to implement the strategy. There was a lack of proper monitoring and communication with the public throughout the creation and implementation process. Cooperation with the region was low, and analyses and future trends and forecasts were missing. The potential of the city had not been fully exploited and no concrete steps were taken to implement the medium-term development plans. In addition, there was a lack 
of sustained commitment on the part of political leadership and staff to put the strategy into practice. The updated strategy aims to address these shortcomings.

The city has defined different visions. These are the following:

- Liberec is the heart of northern Bohemia, amidst unique mountainous nature near the Czech-German-Polish triple border.

- The friendly and open city offers outstanding secondary and tertiary education in a variety of disciplines that train well-trained professionals using the most up-to-date technology.

- The city offers a rich cultural and social life as well as sports opportunities and much more leisure activities for both locals and visitors.

- The quality-of-life conditions of the citizens were provided with a quality environment, plenty of workplaces, and a modern urban management style that is open to cooperation with all sectors.

- In addition to the vision, the city has set additional global goals:

- An attractive city for both residents and tourists, with a functional living center, a diverse natural environment in the immediate vicinity of the city, as well as suitable conditions for sports and other leisure activities.

- Balanced and sustainable economic development is based on the use of modern technologies and the cooperation of individual entities with universities and research centers.

- The high standard of living of city dwellers increases the attractiveness of the city in several areas, for the current inhabitants and for newcomers as well.

- A modernly managed city that cooperates with neighboring municipalities, cities, as well as the county of Liberec, the "Euroregion Nisa", the city's residents, the business community, the civil sector and other stakeholders.

- Based on these, the defined strategic goals focus on the following areas:

- Competitive economy and entrepreneurship (enterprise, science, research, innovation, labor market, tourism),

- Quality of life (education, health, social services, housing, security, culture, sport and leisure),

- Environment and public areas (urban vegetation, suburban landscape, nature and landscape protection, rivers, waste, sewage, air, public spaces, availability of free space),

- Sustainable mobility and technical infrastructure (transport planning, transport infrastructure, traffic safety, traffic signs and traffic management, barrier-free traffic, nonmotorized transport, sustainable mobility, public utilities, energy management),

- Public administration and civil society, territorial cooperation (management of development, urban communication, control of partnership and cooperation, public services, crisis management, administrative staff). (Město Liberec, 2007; Město Liberec, 2014; Mura \& Machyniak, 2014; Vlacseková, 2019) 


\subsection{Olomouc}

The municipality of Olomouc has created a complex development strategic plan for the period 2017-2023 called "Strategický plán rozvoje města Olomouce", which sets out the future development directions of the city. (Město Olomouc, 2017)

The structure of the goals is primarily based on the problem analysis of the problem tree, which summarizes the most important conclusions of the analytical work and identifies the most important issues and reasons. During the analysis, a further 6 key issues were identified within the main issues and divided into different columns. Subsequently, a total of two working sessions were held. At the first meeting, the objectives related to the topic were presented and the members of the working group discussed the formulation of the objectives, the objective focus and implementation of the objectives, and the proposals for the establishment of contact persons and relevant departments. Subsequently, an external consultant worked out the goals, creating so-called "goal descriptions". The first version of the tender section was presented on 18 September 2017 at the second public debate on the city's development strategy. Nearly forty active citizens attended the public hearing, vigorously discussing the proposals and other interesting suggestions were presented as well. Relevant suggestions from citizens were incorporated into the draft and this version of the draft was shared with the members of the working group for their further comments. After that, a second meeting of the working groups was held to finalize the content of each objective, including the definition of indicators to measure the achievement of the objectives. (Město Olomouc, 2017)

The final structure of the proposal was formulated as a result of the working groups, the strategic management committee and the public hearing. The proposed part of the strategic plan is divided into four pillars, representing the main thematic areas. These are the following:

- Pillar 1: Competitive and creative Olomouc,

- Pillar 2: Olomouc - the pearl of Europe,

- Pillar 3: Sustainable Olomouc,

- Pillar 4: Olomouc - the functional center of the region.

Within each pillar, 5-7 specific goals were set. The strategic plan contains a total of 23 objectives, within which a further 87 main activities have been identified. (Město Olomouc, 2017)

\subsection{Plzeň}

The city of Pilsen has been working for several years to improve the quality of life of citizens and visitors to the metropolis with smart and modern solutions that make prosperity easier and more enjoyable. So it was involved in the global concept of smart cities. In the future, Pilsen will not only be a city of culture, sports, industry and beer, but also a center of innovation, cybernetics, science and research. In addition, Pilsen has set the following goals for the next years: 
- Improving the quality of life of generations,

- Providing a safe city for the visitors and Pilsen itself,

- Developing a forward-looking labor market and linking the education system to practice,

- Improving the urban environment and increasing preparedness for climate change,

- Revitalize the city center,

- Raising awareness in Pilsen outside the city. (Pecuch, 2018; Město Plzeň, 2020)

Pilsen wants to be an economically strong, modern and competitive city in Europe. Pilsen focuses on innovative industry and the localization of high value-added production in modern industries. (Smart City Plzen, 2019)

The city sees the development of education and increasing its level as a key factor in competitiveness, which ensures high employment and a precondition for the development of the city's economic base. Its purpose is the unique composition of the education offered. (Smart City Plzen, 2019)

It facilitates the transfer of know-how from universities and research to practice through direct and indirect support for modern tools such as technology parks, information technology centers, innovation centers, conferences and symposia. (Plzen, 2019)

Attractive housing supply with the aim of keeping school leavers in the city and attracting educated and professionally qualified people for whom Pilsen will no longer have a "black city" image. (Smart City Plzen, 2019)

The city of Pilsen will grow as a cultural and social center, not only within the region but also more widely. It develops the offer of services and leisure opportunities for the residents and visitors of the city. In the development of tourism, it focuses on supporting important cultural and sporting events as well as congress tourism. The city offers its center to people and makes the space attractive for leisure and thus an attractive space for business. Pilsen will find partners, visitors and customers in Europe and in return will offer cooperation as well as business and leisure. (Smart City Plzen, 2019)

The city area and its immediate surroundings will be perceived as works of art, emphasizing the balance of each component, connecting the center with its surroundings, connecting urban units, colors and their effects on residents, cleanliness and harmony of public spaces, consistent use of environmentally friendly technologies to protect the environment and uphold the principle of sustainable development in the further construction and management of urban development. (Smart City Plzen, 2019)

\subsection{Ostrava}

The development plan in Ostrava lists the innovation centers and illustrates the most important such facilities.

Firstly, there is the IT4Innovations center. The IT4Innovations is a research center with strong international connections. The central topics of IT4Innovations research are large data processing and analysis, machine learning, development of parallel scalable algorithms, demanding engineering solutions, tasks and modelling of nanotechnologies. Since its founding in 2011, the prestigious pan-European IT4Innovations research has been a member 
of PRACE (European Advanced Computing Partnership) infrastructure, where it represents the Czech Republic. (IT4innovations, 2019)

The BIC Ostrava Business Innovation Center was established in 1993 and its mission is to support and consult in various areas of market activities. It offers comprehensive services for start-ups and developing companies.

In addition to consulting and training, it provides services in its own industrial application development center. It aims to create the conditions for research and development activities, especially for small and medium-sized enterprises that are interested in innovating their products and technologies, however do not have the necessary background and equipment for this activity. It focuses on hydraulics, pneumatics, tribotechnics and proactive diagnostics. Currently, BIC Ostrava s.r.o. provides comprehensive services in technology transfer, innovation, investment projects, project management, research and development. (Bic, 2019; Čapošová, 2015)

The Nanotechnology Center (CNT) was established on 1 February 2007 from the VÚCHEM (Vysokoškolský ústav chemie materiálů) as a university institute of the Technical University of Ostrava (VŠB-TUO) and the first science and technology center in the Czech Republic, the name of which contains nanotechnologies. The activities of the Nanotechnologies Center focus on the research, preparation and analysis of materials, especially those measuring nanometers (10-9 m). The Center's world-famous scientists and experts develop and participate in scientific research activities such as nanocomposites, nanomaterials with photo functional and antibacterial properties, friction composites or sorption materials, and the toxicity of nanoparticles and their effects on the environment and living organisms, etc. (Centrum nanotechnologií, 2019)

The ENET center aims to research and develop renewable energy sources without adverse effects on the environment, including new transport and energy raw material processing technologies, their efficient energy conversion and modern solutions for so-called micro-networks with electrical and thermal energy storage. ENET will also focus on the priorities set out in Horizont 2020 and will develop projects in the framework of calls for new renewable energy technologies as well as for clustering, energy, smart grids and smart cities. (Centrum Enet, 2019)

4Medical Innovations is a technologically advanced biomedical center. It focuses on the most effective use of the results of basic research in clinical practice. Specific areas include cell manipulation, biotechnology, bio pharmacy, and diagnostics in human cells and genetics. The Center offers a wide range of ready-to-use laboratory development and manufacturing facilities in accordance with GMP regulations; direct access to international cooperation with innovative trade organizations and investors; close liaison and collaboration with the clinical departments of the University Hospital during clinical examinations. (4Medical Innovations, 2019)

The city of Ostrava has clearly started to develop. In 2018, it again upgraded its Moodys' rating, in this case to A1 positive. The Concerns multimodal logistics center will soon be completed in its entirety. Environmental measures are also a priority: environmentally conscious living, green areas, bike paths, a bike-sharing system and, last but not least, the 
creation of a new university once the city has received the necessary permits. In addition, there are a number of large-scale investments underway in the city and the city of Ostrava is increasingly moving towards the SMART CITY-based group of cities.

\subsection{Brno}

The land use plan is expected by the end of 2022, which will include wider housing construction and more effective land measures. Urban transport needs major improvements, so renovating the city center avenue is one of the primary goals. The entire tram sections in the direction of Bystrc will be renovated and built from September next year. This will also significantly speed up the completion of the Žabovřeská I. part. (Brno 2050, 2019)

The handover of the station is, of course, also linked to transport. Although this is a public investment, the government and the Ministry of Transport are currently taking the next steps, but this project is also under development. The city of Brno is preparing the infrastructure related to the necessary projects, including the availability of a new public transport station. (Program Strategy Strategy, 2019; Hanáčková \& Bumbalová, 2016)

Both the Brno 2050 and the Smart City Brno projects will arrive at their important stations in the near future. The Brno iD project has certain preconditions for further development. The visions for the near future are wide-ranging. Through Brno iD, citizens will be able to book a book in the library or pay for things. In addition, important information about the city might be sent directly via email or to the app, ensuring that citizens are kept informed of the current situation in the city. Using an electronic card, you can enter various cultural events, such as a theater. (Brno 2050, 2019)

The creators of the smart city also see the vision of Brno in creating an application to track citizens. This means that the app calculates how long it takes to go from point A to point $B$ by car, on foot, by public transport. It is important to recognize at this point that one leaves some ecological footprint and social impact when traveling from one place to another. (Brno 2050, 2019)

Špitálka district will also be an important destination in the near future. It is one of the neighborhoods in Brno that was chosen for repair by the Smart City project creators. A modern, low-energy district needs to be created, and it needs to be built in one of the heating plants on Brno Street. The inspiration came from various foreign cities visited by members of Smart City Brno. This district renewal is part of the RUGGEDISED program. In five years, the site will have to be converted to a low-energy environment with sustainable urban transportation. The project aims to change the city according to the needs of citizens using modern technologies and procedures. This project should be implemented in 2020. (Brno 2050, 2019; Smart City Brno, 2019)

\section{Discussion}

In conclusion, in almost all of the listed cities, the primary basic goal is to improve the quality of life of the residents of the city. Within this, the most important areas are the economy (mainly creating new job opportunities), safety (social, transport or risk management, etc.), transport (construction of new roads, renovation of existing ones, 
reorganization of transport, etc.), social services (elderly, sick, improvement of care for people with disabilities), education (schools, research centers, developments, innovations, etc.), environment (environmental protection, pollution abatement, use of alternative environmentally friendly technologies, etc.), information and communication technologies (introduction and development of electronic information services, mobile applications, electronic rentals, etc.) and tourism (creating an attractive cityscape, expanding opportunities, creating hiking and cycling trails, etc.).

Of course, the areas of development listed receive an unequal, different emphasis in each city. In each case, the location of the city plays a big role. The opportunities offered by each natural endowment are important, but at the same time, for example, the role of transport hubs (motorways, railway junctions, airports, etc.) that determine the opportunities of the city. In addition to these, there are factors such as the history of the city and the neighboring area. These factors are (mostly) not affected by the city. One can only adapt to the natural conditions by noticing and taking advantage of the opportunities offered. And some disadvantages should be tried to be reduced or made insignificant - for example, by focusing on other areas.

Municipalities update and change each development plan at regular intervals (usually every 4-5 years) according to particular changes. It happens that some of the set goals have been achieved, in which case further development may be a future goal, resp. maintaining the current status quo. However, in some cases, the goal may not be achieved or may only be partially achieved. In such cases, it is necessary to analyze the situation and identify the individual obstacles that have hindered development. Once these have been identified, they need to be removed, and further work can begin to achieve the main goal. It is an unfortunate unique phenomenon that in many cases the body of representatives is replaced after the elections and the new mayor sets completely opposite goals in their new program, sweeping away the successful plans and insights of previous years. Of course, they are not the only ones to make such decisions, but they also hire various independent experts to assess the situation and develop new sub-plans. In this case, however, the actual independence of the professionals can also be questioned, and in general the principle of "new mayor and new professionals" is applied, thus previous plans become null and void.

In the course of our research, we encountered several limits that we had to deal with and hindered the most relevant results. One such constraint was the change in development plans after new leaders came to the helm of the city, with the result that in many cases they came up with completely new plans instead of the original ones. The next problem was caused by the collection of relevant data and the restrictions in place since the COVID-19 pandemic also hampered our research.

Future directions include the expansion of our research area to examine the development plans of several Central European countries along the defined criteria, and we would also like to include the effects of COVID-19 in the research questions. We would like to conduct interviews with mayors or municipality representatives responsible for development. 


\section{References}

4Medical Innovations. (2019). Základní informace. http://www.4medi.cz/o-biotech-parku.html

Ankers, S., Kaiserman, D., \& Shepley, C. (2020). Grotton Revisited: Planning in Crisis? Routledge.

BIC Ostrava, s. r. o. (2019). BIC Ostrava. https://www.bicova.cz/

Brno 2050. (2019). Programová část strategie \#brno2050.

https://brno2050.cz/pdf/Strategie_BRNO_2050_programova_cast_FINAL.pdf

Čapošová, E. (2015). The importance of human resources in quality management in public administration. Acta Oeconomica Universitatis Selye, 4(1), 34-41.

Čejka, M. (2009). Město Liberec v kulturologické perspektivě. Univerzita Karlova: Praha.

Centrum Enet. (2019). http://cenet.vsb.cz/cz/

Centrum Nanotechnologií. (2019). http://www.cnt.vsb.cz/

ČSÚ. (2018). Počet obyvatel v obcích České republiky k 1. 1. 2018. https://www.czso.cz/documents/10180/61546986/1300721803.pdf/bcb6d91b-626f-41fd-a7053f7a49265b4d?version $=1.0$

ČSÚ. (2019). Veřejná database. [Data set]. Retrieved February 04, 2021 from https://vdb.czso.cz/vdbvo2/faces/cs/index.jsf?page=uziv-dotaz\#_

Faktografické listy Ostrava. (2019). Město Ostrava ve faktech a číslech. https://www.ostrava.cz/cs/podnikatelinvestor/ekonomicky-profil-mesta/publikace/ke-stazeni/FL_2019_CZ_final.pdf

Hanáčková, D., \& Bumbalová, M. (2016). Innovations in self-government. Acta Oeconomica Universitatis Selye, $5(2), 88-96$.

Hastings, N. A. J. (2021). Physical Asset Management. Springer.

IT4Innovations. (2019). https://www.it4i.cz/

Jašková, D. (2019). Assessment of social development in Slovakia in the context of human resources. Central European Journal of Labour Law and Personnel Management, 2(2), 21-32.

Jiříčková, T. (2011). Faktické obyvatelstvo města Olomouce. Univerzita Palackého v Olomouci.

Město Liberec. (2007). Strategie rozvoje Statutárního města Liberec 2007 - 2020.

https://www.liberec.cz/files/dokumenty/odbory/odbor-strategickeho-rozvojedotaci/strategie_2007_2020.pdf

Město Liberec (2014). Aktualizace Strategie Rozvoje Statutárního Města Liberec 2014-2020. https://www.liberec.cz/files/dokumenty/odbory/odbor-strategickeho-rozvoje-dotaci/aktualizace-strategierozvoje-statutarniho-mesta-liberec-2014-2020.pdf

Město Liberec (2021). Geografické údaje. https://www.liberec.cz/cz/mesto-samosprava/profil-statutmesta/geograficke-udaje/

Město Olomouc. (2017). Strategický plán rozvoje města Olomouce. Zefektivnění procesu strategického ř́zení ve městě Olomouci včetně tvorby strategického plánu a optimalizace procesů na úřadě. https://www.dataplan.info/img_upload/7bdb1584e3b8a53d337518d988763f8d/sp-olomouc-navrhova-aanalyticka-cast.pdf

Město Plzeň. (2020). Město př́ležitosti Plzeň. https://www.plzen.eu/Files/MestoPlzen/web2013/Obcan/o_meste/vize_mesta/170605_Plzen_profil_mesta_ CZE.pdf

Mura, L., \& Machyniak, J. (2014). Ethical aspects of public administration. In Hradec Economic Days 2014: Economic Development and Management of Regions. (pp. 59-65).

Pecuch, M. (2018). Strategie města Plzně. https://www.plzen.eu/urad/verejne-dokumenty/strategiemesta/strategie-mesta-plzne.aspx

Rechnitzer, J. (2019). Gondolatok, vélemények magyar településfejlesztési programokról. Tér és Társadalom, 3(1), 3-26. https://doi.org/10.17649/TET.33.1.3069

Smart City Brno. (2019). https://www.smartcitybrno.cz/ruggedised/

Smart City Plzen. (2019). https://smartcity.plzen.eu/o-smart-city-plzen/

Sykora, L. (2002). Suburbanizace a její sociální, ekonomické a ekologické dôsledky. Ústav pro ekopolitiku.

Vlacseková, D. (2019). Comparative analysis of motivation of civil servants and public servants in the local state administration - case study of Slovakia. Central European Journal of Labour Law and Personnel Management, 2(1), 74-93.

Zeman, J. (2009). Architektonický a urbanistický vývoj Liberce 1352-2006. Univerzita Karlova. 